\title{
PENGARUH PROFITABILITAS, LIKUIDITAS DAN KEBIJAKAN DIVIDEN TERHADAP NILAI PERUSAHAAN SEKTOR INDUSTRI BARANG KONSUMSI DI BEI
}

\author{
Kadek Yuliana Dewi ${ }^{1}$ \\ Henny Rahyuda ${ }^{2}$ \\ ${ }^{1,2}$ Fakultas Ekonomi dan Bisnis Universitas Udayana, Bali, Indonesia \\ email: Dewiy65@yahoo.com
}

\begin{abstract}
ABSTRAK
Tujuan dari penelitian ini adalah untuk mengetahui signifikansi pengaruh profitabilitas, likuiditas dan kebijakan dividen terhadap nilai perusahaan. Penelitian ini dilakukan pada perusahaan sektor industri barang konsumsi di Bursa Efek Indonesia (BEI) periode 2016-2018. Jumlah sampel pada penelitian ini adalah 17 perusahaan dengan metode purposive sampling. Pengumpulan data dilakukan dengan metode observasi non partisipan yaitu melalui data laporan keuangan yang dipublikasikan pada website resmi BEI yaitu www.idx.co.id. Hasil analisis diperoleh bahwa profitabilitas berpengaruh positif signifikan terhadap nilai perusahaan. Likuiditas dan kebijakan dividen berengaruh negatif tidak signifikan terhadap nilai perusahaan. Hal ini berarti profitabilitas merupakan faktor utama yang paling mempengaruhi nilai perusahaan dan diperhatikan oleh investor untuk berinvestasi.

Kata Kunci: nilai perusahaan, profitabilitas, likuiditas, kebijakan dividen
\end{abstract}

\begin{abstract}
The purpose of this study is to determine the significance of the effect of profitability, liquidity and dividend policy on firm value. This research was conducted at the consumer goods industry sector companies on the Indonesia Stock Exchange (BEI) 2016-2018 period. The number of samples in this study were 17 companies with a purposive sampling method. Data collection was carried out using a non-participant observation method, through financial statement data published on the IDX's official website, www.idx.co.id. The results of the analysis showed that profitability had a significant positive effect on firm value. Liquidity and dividend policy have a significant negative effect on firm value. This means that profitability is the main factor that most influences the value of the company and is considered by investors to invest.

Keywords: firm value, profitability, liquidity, dividend policy
\end{abstract}




\section{PENDAHULUAN}

Pasar modal adalah pasar untuk berbagai instrumen keuangan jangka panjang yang bisa diperjualbelikan, baik dalam bentuk utang maupun modal sendiri. Keberadaan Pasar Modal di Indonesia sangat diperlukan oleh perusahaan karena dengan menerbitkan saham di Bursa Efek, dapat membuat investor tertarik untuk menanamkan modalnya dan dapat menghasilkan dana bagi perusahaan yang dipergunakan untuk kegiatan operasional perusahaan sekaligus dapat meningkatkan nilai perusahaan (Sudiani \& Darmayanti, 2016). Bagi perusahaan yang menerbitkan saham di Pasar Modal, harga saham yang diperjualbelikan di bursa merupakan indikator dari nilai perusahaan, atau bisa dikatakan bahwa harga saham merupakan cerminan dari nilai perusahaan. Perusahaan yang telah go public, nilai perusahaan dapat terlihat dari harga sahamnya. Berbeda dengan perusahaan yang tidak go public, nilai perusahannya dapat diukur dengan harga jual ketika perusahaan tersebut dijual (Sartono, 2014:9)

Memaksimumkan nilai perusahaan atau memaksimumkan kesejahteraan para pemegang saham merupakan tujuan utama keputusan keuangan. (Wiagustini, 2014:9) menyatakan bahwa nilai perusahaan adalah harga yang bersedia dibayar oleh calon pembeli apabila perusahaan dijual. Nilai perusahaan adalah harga pasar saham yang terbentuk diantara pembeli dan penjual saat melakukan transaksi yang menjadi cerminan dari nilai aset perusahaan yang sesungguhnya (Sudiani \& Darmayanti, 2016). Semakin tinggi nilai perusahaan maka akan diikuti oleh tingginya kemakmuran para pemegang saham (Brigham, E.F. \& Houston, 2018:7)

Tujuan meningkatkan nilai perusahaan adalah untuk menarik minat investor berinvestasi terhadap suatu perusahaan (Pranama \& Mustanda, 2016) Nilai perusahaan akan menggambarkan kinerja dan kondisi perusahaan dimasa lalu, saat ini dan prospeknya pada periode mendatang (Astuty, 2017) Seorang investor harus bisa memanfaatkan semua informasi dari laopran keuangan untuk melakukan analisis pasar dan melakukan investasi dengan harapan mendapat keuntungan. Bagi investor harga saham yang tinggi menandakan bahwa tingginya tingkat kemakmuran dari para pemegang saham perusahaan.

Tolak ukur yang sering dipakai untuk mengukur nilai perusahaan adalah price book value (PBV) yaitu rasio yang menunjukkan seberapa jauh suatu perusahaan mampu menciptakan nilai perusahaan yang relatif terhadap jumlah modal yang diinvestasikan. PBV dapat diukur melalui harga pasar saham terhadap nilai buku per lembar saham. Semakin tinggi price book value (PBV) memberikan indikasi bahwa investor memberikan apresiasi yang tinggi terhadap saham perusahaan, sebab nilai perusahaan yang tinggi menunjukkan kemakmuran dari pemegang saham (Velankar et al., 2017).

Terdapat banyak faktor yang mempengaruhi nilai perusahaan diantaranya yaitu profitabilitas, likuiditas, ukuran perusahaan, leverage, pertumbuhan, investment opportunity set, kebijakan dividen dan struktur modal (Brigham, E.F. \& Houston, 2018:9) Pada keputusan investasi, perusahaan dihadapkan pada keputusan tentang berapa dana yang harus diinvestasikan pada aktiva lancar dan aktiva tetap agar bisa membayar kewajiban jangka pendek tepat waktu. Melalui seluruh aktiva yang tersedia perusahaan harus dapat mengoptimalkan penggunaan modal dan sumber dananya sehingga dapat memperoleh laba. Perusahaan harus mengambil 
keputusan berapa dari laba tersebut yang akan diinvestasikan kembali pada perusahaan dalam bentuk laba ditahan dan berapa yang harus dibagikan kepada pemegang saham dalam bentuk dividen. Keputusan inilah yang dikenal dengan kebijakan dividen.

Faktor pertama yang mempengaruhi nilai perusahaan dalam penelitian ini adalah profitabilitas. Menurut (Husnan, 2015:317) profitabilitas merupakan tingkat keuntungan bersih yang mampu diraih oleh perusahaan pada saat menjalankan operasinya. Semakin baik pertumbuhan profitabilitas perusahaan, maka prospek perusahaan di masa depan dinilai semakin baik bagi investor. Profitabilitas yang digunakan dalam penelitian ini diproksikan dengan Return on Equity (ROE), yaitu kemampuan perusahaan untuk menghasilkan laba melalui efisiensi penggunaan modal sendiri, yang dapat dihitung dengan membagi laba setelah pajak dengan modal sendiri.

Semakin tinggi ROE maka posisi pemilik perusahaan semakin kuat dan memperlihatkan besarnya tingkat pengembalian atas investasi dari pemegang saham. Semakin tinggi profitabilitas perusahaan maka nilai perusahaan semakin tinggi. Investor lebih tertarik berinvestasi pada perusahaan dengan tingkat profitabilitas yang tinggi, tingginya minat investor berdampak pada meningkatnya harga saham. (Sharif et al., 2015) menyatakan bahwa profitabilitas berpengaruh positif signifikan terhadap nilai perusahaan. Penelitian yang dilakukan oleh (Suarnawa \& Abundanti, 2016), Sudiani \& Darmayanti (2016) bahwa profitabilitas berpengaruh positif dan signifikan terhadap nilai perusahaan. Hasil yang berbeda dari penelitian sebelumnya yang menyatakan bahwa profitabilitas tidak berpengaruh signifikan terhadap nilai perusahaan oleh (Damayanti et al., 2018) dan (Faraz et al., 2017) juga menemukan bahwa profitabilitas berpengaruh negatif signifikan terhadap nilai perusahaan.

Faktor kedua yang mempengaruhi nilai perusahaan dalam penelitian ini adalah likuiditas. Menurut (Sartono, 2014:114) likuiditas merupakan kemampuan perusahaan untuk memenuhi kewajiban finansial yang berjangka pendek tepat waktu. Current ratio (CR) sebagai proksi dari likuditas pada penelitian ini merupakan rasio untuk mengukur kemampuan perusahaan dalam memenuhi hutang lancar dengan menggunakan seluruh aktiva lancar yang dimiliki (Sudiani \& Darmayanti, 2016).

Semakin tinggi likuiditas maka semakin tinggi nilai perusahaan karena investor menganggap perusahaan dengan likuiditas yang tinggi memiliki kinerja perusahaan yang baik. Perusahaan dianggap mampu membayarkan seluruh kewajiban jangka pendeknya secara tepat waktu dan mampu memberikan dividen yang semakin besar kepada pemegang saham. Keadaan ini dapat membuat calon investor percaya terhadap perusahaan tersebut untuk berinvestasi sehingga dapat meningkatnya nilai perusahaan.

Penelitian yang dilakukan oleh Heryanto (2016) menyatakan bahwa likuiditas berpengaruh positif signifikan terhadap nilai perusahaan. Hasil yang sama didapatkan dari penelitian yang dilakukan oleh (Suarnawa \& Abundanti, 2016) dan (Tuil et al., 2017). Hasil berbeda di dapat oleh (Damayanti et al., 2018) yang menemukan bahwa likuiditas berpengaruh negatif signifikan terhadap nilai 
perusahaan. Hasil ini sejalan dengan penelitian yang dilakukan (Memon et al., 2017) dan (Sitorus \& Elinarty, 2017).

Faktor ketiga yang mempengaruhi nilai perusahaan pada penelitian ini adalah kebijakan dividen. Menurut (Wiagustini, 2014:286) kebijakan dividen adalah keputusan keuangan yang dilakukan oleh perusahaan setelah perusahaan beroperasi dan memperoleh laba. Kebijakan dividen dalam penelitian ini diukur dengan dividen payout ratio (DPR) yang merupakan persentase laba bersih yang dibayarkan sebagai dividen tunai (Brigham, E.F. and Houston, 2018:211). Melalui dividen payout ratio inilah bisa ditentukan besarnya dividen per lembar saham

Dividen Payout Ratio (DPR) menentukan besarnya laba yang akan dibagi dalam bentuk dividen dan laba ditahan sebagai sumber pendanaan. Kebijakan dividen berpengaruh terhadap harga saham perusahaan, karena kenaikan dividen tunai berdapak pada kenaikan harga saham. Adanya kenaikan jumlah dividen tunai menyebabkan perusahaan dipandang memiliki prospek yang baik di masa depan yang mampu meningkatkan nilai perusahaan (Putra. dan Lestari, 2016).

Penelitian yang dilakukan oleh (Adefemi et al., 2018)) menemukan bahwa kebijakan dividen berpengaruh positif signifikan terhadap nilai perusahaan. Hal yang sama didapatkan dari penelitian yang dilakukan oleh (Ayem \& Nugroho, 2016), (Adesina et al., 2017). Berbeda dari hasil penelitian yang di dapatkan (Topak \& Dereli, 2018) yang menunjukkan bahwa kebijakan dividen tidak berpengaruh signifikan terhadap nilai perusahaan.

Ketertarikan investor terhadap suatu perusahaan disebabkan oleh informasiinformasi yang diberikan dalam laporan keuangan perusahaan. Pada saat laporan keuangan dipublikasikan menunjukkan peran dari signaling theory. Signaling theory menjelaskan mengenai bagaimana perusahaan memberikan sinyal kepada pengguna laporan keuangan untuk menghindari asimetris informasi.

Penelitian ini dilakukan pada perusahaan Manufaktur khususnya pada sektor industri barang konsumsi di Bursa Efek Indonesia periode 2016-2018. Sektor industri barang konsumsi merupakan sektor industri yang memproduksi kebutuhan sehari-hari masyarakat. Sektor ini menarik untuk diteliti karena sektor industri barang konsumsi tergolong sektor yang stabil, sebab permintaannya yang stabil, selalu tumbuh dan berkembang seiring meningkatnya penduduk.

Berdasarkan Tabel 1. nilai rata-rata price book value (PBV) mengalami fluktuasi dan cenderung menurun. Rata-rata PBV sektor industri barang konsumsi di BEI tahun 2016 sebesar 4,40 kemudian menurun di tahun 2017 sebesar 4,36 dan semakin menurun di tahun 2018 menjadi 3,89. Berfluktuasinya nilai PBV di tahun 2016-2018 disebabkan oleh faktor-faktor yang mempengaruhi nilai perusahaan. Beberapa faktor yang dapat mempengaruhi nilai perusahaan diantaranya yaitu profitabilitas, likuiditas serta kebijakan dividen.

Pada Tabel 2. menunjukkan bahwa nilai rata-rata profitabilitas yang di proksikan dengan Return on Equity (ROE) mengalami penurunan dari tahun 20162018, begitu juga dengan likuiditas yang di proksikan dengan Current Ratio (CR) yang mengalami penurunan dari tahun 2016-2018. Berbeda hal nya dengan kebijakan dividen yang di proksikan dengan Dividen Payout Ratio (DPR) terus mengalami peningkatan dari tahun 2016-2018. Naik turunnya rasio-rasio ini yang 
menjadi salah satu dari sekian banyak faktor yang mampu mempengaruhi nilai PBV pada sektor industri barang konsumsi di BEI mengalami fluktuasi.

Tabel 1.

Data Price Book Value (PBV) pada Sektor Industri Barang Konsumsi di Bursa Efek Indonesia Periode 2016-2018

\begin{tabular}{ccccc}
\hline \multirow{2}{*}{ No } & Kode & \multicolumn{3}{c}{ PBV (x) } \\
\cline { 3 - 5 } & Perusahaan & $\mathbf{2 0 1 6}$ & $\mathbf{2 0 1 7}$ & $\mathbf{2 0 1 8}$ \\
\hline 1 & CINT & 0,99 & 0,98 & 0,73 \\
2 & DLTA & 4,37 & 3,84 & 3,75 \\
3 & DVLA & 1,84 & 1,95 & 1,81 \\
4 & GGRM & 3,27 & 4,04 & 3,75 \\
5 & HMSP & 14,51 & 16,13 & 13,74 \\
6 & ICBP & 5,61 & 5,11 & 5,56 \\
7 & INDF & 1,55 & 1,43 & 1,35 \\
8 & KAEF & 6,84 & 5,83 & 5,19 \\
9 & KINO & 2,25 & 1,53 & 1,89 \\
10 & KLBF & 6,01 & 5,97 & 4,89 \\
11 & MERK & 7,44 & 6,24 & 3,02 \\
12 & MYOR & 6,38 & 6,71 & 7,45 \\
13 & ROTI & 5,97 & 5,39 & 2,60 \\
14 & SIDO & 3,05 & 2,99 & 4,27 \\
15 & SKLT & 1,27 & 2,46 & 3,16 \\
16 & TCID & 1,44 & 1,94 & 1,77 \\
17 & TSPC & 1,94 & 1,66 & 1,17 \\
& Rata-rata & 4,40 & 4,36 & 3,89 \\
\hline
\end{tabular}

Sumber: www.idx.co.id (data diolah, 2019)

Tabel 2.

Nilai Rata-Rata Rasio ROE, CR dan DPR pada Sektor Industri Barang Konsumsi di Bursa Efek Indonesia Periode 2016-2018

\begin{tabular}{ccccc}
\hline \multirow{2}{*}{ No } & \multirow{2}{*}{ Variabel } & \multicolumn{3}{c}{ Rata-rata (\%) } \\
\cline { 3 - 5 } & & $\mathbf{2 0 1 6}$ & $\mathbf{2 0 1 7}$ & $\mathbf{2 0 1 8}$ \\
\hline 1 & ROE & 16,75 & 15,53 & 12,18 \\
2 & CR & 347,42 & 338,66 & 308,10 \\
3 & DPR & 47,91 & 51,51 & 54,13 \\
\hline \multicolumn{3}{l}{ Sumber: www.idx.co.id (data diolah, 2019) }
\end{tabular}

Menurut (Brigham, E.F. \& Houston, 2018:187) isyarat atau signal adalah suatu tindakan yang diambil perusahaan untuk memberi petunjuk bagi investor tentang bagaimana manajemen memandang prospek perusahaan. Sinyal ini dapat berupa informasi tentang apa saja yang telah dilakukan oleh perusahaan untuk merealisasikan keinginan pemilik. Teori sinyal merupakan teori yang menjelaskan 
alasan perusahaan menjadi memiliki keinginan untuk mempublikasikan informasi laporan keuangan pada pihak eksternal (Memon et al., 2017) Dorongan perusahaan untuk memberikan informasi laporan keuangan dikarenakan terdapat asimetri informasi antara manajemen perusahaan dan pihak luar. Kondisi asimetri informasi adalah pihak perusahaan mengetahui lebih banyak mengenai informasi perusahaan dan prospek yang akan datang dari pihak luar sehingga tidak dapat diakses oleh investor.

Hubungan teori sinyal (signaling theory) dengan penelitian ini adalah adanya dorongan dari pihak perusahaan untuk menginformasikan laporan keuangannya kepada pihak luar, yang bertujuan untuk menghindari adanya asimetris informasi antara pihak perusahaan dengan pihak eksternal. Melalui laporan keuangan tersebut para investor bisa mengetahui bagaimana kinerja keuangan perusahaan, sebab didalam laporan tersebut berisikan rasio-rasio keuangan yang mencerminakan keadaan perusahaan. Rasio-rasio yang paling sering diperhatikan yaitu diantaranya profitabilitas, likuiditas dan kebijakan dividen dianggap sebagai sinyal bagi investor dalam menilai keadaan perusahaan dan sebagai pertimbangan dalam mengambil keputusan investasi, sebab 3 variabel ini dapat membawa pengaruh terhadap harga saham perusahaan.

Menurut (Wiagustini, 2014:9) nilai perusahaan adalah harga yang bersedia dibayar oleh calon pembeli apabila perusahaan dijual. Semakin tinggi nilai perusahaan, semakin besar kemakmuran yang diterima oleh pemilik perusahaan. Bagi perusahaan yang menerbitkan saham di pasar modal, harga saham yang diperjualbelikan di bursa merupakan indikator dari nilai perusahaan. Menurut (Ong, 2016:2) harga pasar saham ditentukan oleh permintaan dan penawaran yang saat ini diperdagangkan di Bursa Efek. Pada dasarnya harga saham di pasar modal dapat dipengaruhi oleh beberapa faktor, namun salah satunya yang paling dominan yaitu faktor yang berhubungan dengan kondisi fundamental perusahaan.

Nilai perusahaan dapat diukur menggunakan rasio price book value (PBV). (Brigham, E.F. and Houston, 2018:151) menyatakan price to book value (PBV) adalah rasio yang menunjukkan berapa besar perusahaan mampu menciptakan nilai perusahaan yang relatif melalui jumlah modal yang diinvestasikan. Perhitungan PBV dapat melalui perbandingan antara harga saham dengan nilai buku per lembar saham. Semakin tinggi PBV maka semakin tinggi pula tingkat kemakmuran dari para pemegang saham karena membuat investor percaya atas prospek baik perusahaan kedepan. PBV merupakan indikator nilai perusahaan dari sudut pandang keinginan pemegang saham. Pentingnya PBV bagi investor maupun calon investor adalah untuk menentukan keputusan berinvestasi.

PBV merupakan perhitungan atau perbandingan antara market value dengan book value suatu saham sehingga dapat mengukur tingkat harga saham apakah overvalued atau undervalued. Pada penelitian ini PBV digunakan sebagai proksi dari nilai perusahaan. Adapun penelitian lain yang menggunakan PBV sebagai proksi dari nilai perusahaan adalah (Rai Prastuti \& Merta Sudiartha, 2016), (Astuti \& Yadnya, 2019), (Yanti \& Darmayanti, 2019)

Menurut (Kasmir, 2013:196) profitabilitas merupakan faktor yang dapat mempengaruhi nilai perusahaan karena, profitabilitas menjadi aspek penting bagi perusahaan dalam mempertahankan kelangsungan hidup usaha jangka panjang. 
Profitabilitas menurut (Wiagustini, 2014:76) adalah kemampuan perusahaan dalam memperoleh laba dan digunakan sebagai alat untuk mengukur tingkat efektivitas dalam suatu perusahaan. (Dewi, L.S \& Abundanti, 2019) menyatakan pertumbuhan profitabilitas suatu perusahaan merupakan salah satu indikator penting yang dilihat oleh investor saat berinvestasi dalam hal menilai prospek perusahaan dimasa yang akan datang.

Rasio profitabilitas pada penelitian ini diukur menggunakan proksi Return on Equity (ROE) yaitu rasio untuk mengetahui berapa persen diperoleh laba bersih apabila diukur dari modal sendiri (Pranama \& Mustanada, 2016). Perhitungan menggunakan ROE yaitu laba bersih setelah pajak (earning after tax) dibagi dengan total modal sendiri (equity) yang berasal dari modal pemilik perusahaan, laba ditahan, dan cadangan lain yang dikumpulkan perusahaan (Wiagustini, 2014:77). Semakin tinggi ROE maka besar juga kemampuan perusahaan dalam menghasilkan laba dan akan berpengaruh pada peningkatan nilai perusahaan. Profitabilitas yang tinggi menunjukkan prospek perusahaan yang baik diperiode mendatang, sehingga investor akan merespon positif dan nilai perusahaan akan meningkat. (Sharif et al., 2015), (Ayem \& Nugroho, 2016), (Mahdaleta et al., 2016), (Maha Dewi \& Sudiartha, 2017), (Melinda Yanti Putu Diah, 2019) dalam penelitiannya menyatakan bahwa profitabilitas berpengaruh positif dan signifikan terhadap nilai perusahaan. Maka hipotesis yang dapat dibuat adalah:

$\mathrm{H}_{1}$ : Profitabilitas berpengaruh positif dan signifikan terhadap nilai perusahaan.

Menurut (Wiagustini, 2014:85) likuiditas merupakan kemampuan perusahaan untuk memenuhi kewajiban finansialnya dalam jangka pendek dengan dana lancar yang tersedia. Dari sisi kreditur semakin tinggi nilai likuiditas perusahaan maka semakin baik, karena perusahan mampu membayarkan kewajiban jangka pendeknya secara tepat waktu (Patricia et al., 2018). Likuiditas yang tinggi tak selalu menguntungkan bagi pemegang saham, karena akan berdampak pada banyaknya dana menganggur yang sebenarnya dana tersebut dapat dimanfaatkan sebagai investasi agar meningkatkan keuntungan perusahaan.

Rasio likuiditas pada penelitian ini diukur menggunakan proksi Current Ratio (CR). Current Ratio (CR) menunjukkan seberapa besar kewajiban lancar mampu didanai oleh aset lancar (Brigham, E.F.\& Houston, 2018:83) Current ratio dapat dihitung dengan membandingkan antara seluruh aktiva lancar yang dimiliki perusahaan dengan hutang jangka pendek. Tingginya nilai CR maka semakin besar keamampuan perusahaan memenuhi kewajiban jangka pendeknya sehingga mampu meningkatkan nilai perusahaan (Sartono, 2014:87).

Tingginya rasio likuiditas menunjukkan besarnya kemampuan perusahaan dalam memenuhi kewajiban jangka pendek tepat pada waktunya dan juga mampu dalam memenuhi operasionalnya serta dalam pemberian dividen kepada para investor (Astuti \& Yadnya, 2019). Hal ini dapat meningkatkan permintaan investor untuk berinvestasi pada perusahaan dengan likuiditas yang tinggi, sehingga menyebabkan peningkatan nilai perusahaan. Menurut (Suarnawa \& Abundanti, 2016), (Putra \& Lestari, 2016), (Tuil et al., 2017), (Melinda Yanti Putu Diah, 2019) menemukan bahwa likuiditas berpengaruh positif dan signifikan terhadap nilai perusahaan. Maka hipotesis yang dapat dibuat adalah:

$\mathrm{H}_{2}$ : Likuiditas berpengaruh positif dan signifikan terhadap nilai perusahaan. 
Kebijakan dividen merupakan keputusan keuangan yang dilakukan oleh perusahaan setelah perusahaan beroperasi dan memperoleh laba (Wiagustini, 2014:286). Kebijakan dividen juga dapat diartikan sebagai keputusan tentang seberapa banyak laba saat ini yang akan dibayarkan sebagai dividen daripada ditahan untuk diinvetasikan kembali dalam perusahaan (Gede \& Artini, 2019). Pembayaran dividen ditujukan untuk mengurangi ketidakpastian, karena dapat mengurangi risiko tingkat keuntungan yang diisyaratkan oleh pemegang saham dan mengurangi konflik kepentingan antar manajer perusahaan dengan para pemegang saham (Melinda Yanti Putu Diah, 2019).

Argumentasi pengaruh kebijakan dividen terhadap nilai perusahaan dijelaskan dalam beberapa teori dividen yaitu Dividend irrelevance theory, teori ini ditemukan oleh Miller dan Modigliani (1961) yang menyatakan bahwa kebijakan dividen tidak mempengaruhi harga pasar saham perusahaan dan nilai perusahaan. Pembayaran dividen tidak berpengaruh terhadap kemakmuran pemegang saham karena nilai perusahaan ditentukan oleh earning power dari aset perusahaan. Maka dapat dikatakan bawha nilai perusahaan ditentukan oleh keputusan investasi.

Bird-in-the-hand theory, teori ini ditemukan oleh Gordon (1962) dan Lintner (1956, 1963) yang menyatakan jika dividen yang dibagikan perusahaan semakin tinggi, maka harga pasar saham perusahaan juga akan semakin tinggi dan begitu sebaliknya. Hal ini disebabkan karena pembagian dividen dapat mengurangi ketidakpastian investor. Para investor lebih yakin jika menerima dividen dibandingkan jika menerima capital gain dari laba yang ditahan, karena Gordon and Lintner berpendapat bahwa kemungkinan capital gain yang diharapkan lebih berisiko dibanding dengan pembayaran dividen yang sudah pasti.

Tax preference theory and clientile effect, teori ini di temukan oleh Litzenberger dan Ramaswarny (1979) yang menyatakan bahwa semakin tinggi dividen payout ratio suatu perusahaan, maka nilai perusahaan tersebut akan semakin rendah. Hal ini disebabkan oleh perbedaan pajak antar dividen dengan capital gain serta perbedaan pengenaan pajak bagi setiap investor. Investor lebih suka untuk menerima capital gain yang tinggi dibandingkan dengan dividen yang tinggi. Berkaitan dengan clientile effect, terdapat dua kelompok investor yaitu investor yang lebih menyukai untuk meperoleh pendapatan saat ini dalam bentuk pembagian dividen, namun ada juga investor yang menyukai untuk menginvestasikan kembali pendapatan mereka, karena investor ini berada dalam tarif pajak yang cukup tinggi.

Dividend payout ratio (DPR) menunjukkan besarnya rasio pembayaran dividen tunai kepada pemegang saham. Pada penelitian ini kebijakan dividen diproksikan dengan dividend payout ratio (DPR) yang membandingkan jumlah dividen yang dibayarkan dengan laba bersih yang diperoleh perusahaan. DPR digunakan untuk mengukur persentase dividen tunai yang diberikan perusahaan kepada para pemegang saham atas laba per lembar saham yang dihasilkan.

Menurut teori information content of dividend, investor akan melihat kenaikan dividen sebagai sinyal positif atas prospek perusahaan di masa depan, untuk dapat meningkatkan nilai perusahaan maka perusahaan cenderung meningkatkan dividen payout ratio (DPR). Besarnya dividen cenderung akan membuat para investor tertarik untuk berinvestasi, sehingga dapat meningkatkan 
permintaan saham di pasar. Permintaan saham yang tinggi menyebabkan meningkatnya harga saham dan nilai perusahaan. Penelitian yang dilakukan oleh (Sharif et al., 2015), (Rai Prastuti \& Merta Sudiartha, 2016), (Adefemi et al., 2018), (Musabbihan \& Purnawati, 2018) membuktikan bahwa kebijakan dividen berpengaruh positif dan signifikan terhadap nilai perusahaan. Maka hipotesis yang dapat dibuat adalah:

$\mathrm{H}_{3}$ : Kebijakan dividen berpengaruh positif dan signifikan terhadap nilai perusahaan

\section{METODE PENELITIAN}

Penelitian ini dilakukan pada perusahaan sektor industri barang konsumsi di Bursa Efek Indonesia (BEI) periode 2016-2018. Obyek dalam penelitian ini adalah nilai perusahaan (PBV), profitabilitas (ROE), likuiditas (CR) dan kebijakan dividen (DPR) pada perusahaan sektor industri barang konsumsi di Bursa Efek Indonesia periode 2016-2018. Variabel bebas dalam penelitian ini adalah Profitabilitas (X1), Likuiditas (X2) dan Kebijakan Dividen (X3). Variabel terikat pada penelitian ini adalah nilai perusahaan $(\mathrm{Y})$.

Nilai perusahaan pada penelitian ini diproksikan dengan price book value (PBV). PBV dalam satuan kali (x) dapat dihitung dengan rumus sebagai berikut:

$$
\mathrm{PBV}=\frac{\text { Harga Per Lembar Saham }}{\text { Nilai Buku Per Lembar Saham }}
$$

Profitabilitas pada penelitian ini diproksikan dengan Return on Equity (ROE). ROE dalam satuan persen (\%) dapat dihitung dengan rumus sebagai berikut:

$$
\mathrm{ROE}=\frac{\text { Laba Setelah Pajak }}{\text { Modal Sendiri }} \times 100 \%
$$

Likuiditas pada penelitian ini diproksikan dengan Current Ratio (CR). CR dalam satuan persen (\%) dapat dihitung dengan rumus sebagai berikut:

$$
\mathrm{CR}=\frac{\text { Aktiva Lancar }}{\text { Pasiva lancar }} \times 100 \%
$$

Kebijakan dividen dalam penelitian ini diproksikan dengan Dividend Payout Ratio (DPR). DPR dalam satuan persen (\%) dapat dihitung dengan rumus sebagai berikut:

$$
\text { DPR }=\frac{\text { Dividen } \text { Per saham }}{\text { Laba Per Saham }} \times 100 \%
$$

Jenis data pada penelitian ini adalah data kuantitatif berupa angka, data dalam bentuk laba, harga, modal sendiri, aktiva lancar, hutang lancar dan dividen. Sumber data pada penelitian ini adalah sumber data sekunder yang diperoleh dari laporan keuangan tahunan perusahaan sektor industri barang konsumsi di BEI periode 2016-2018, yang dipublikasi pada website resmi BEI yaitu www.idx.co.id.

Populasi dalam penelitian ini adalah seluruh perusahaan sektor industri barang konsumsi di Bursa Efek Indonesia (BEI) dengan jumlah sebanyak 53 perusahaan. Jumlah sampel yang digunakan yaitu sebanyak 17 perusahaan, dengan metode purposive sampling. Pengumpulan data dilakukan dengan metode observasi non partisipan yaitu melalui data laporan keuangan yang dipublikasikan pada website (www.idx.co.id). Teknik analisis data yang digunakan pada penelitian ini 
yaitu analisis deskriptif, analisis regresi linier berganda, uji asumsi klasik yang terdiri dari uji normalitas, uji autokorelasi, uji heteroskedastisitas, dan uji multikolinieritas, serta dilakukan uji kelayakan model (uji f), uji koefisien determinasi majemuk $\left(\mathrm{R}^{2}\right)$ dan uji hipotesis (uji $\left.\mathrm{t}\right)$.

\section{HASIL DAN PEMBAHASAN}

Penelitian ini dilakukan pada perusahaan sektor industri barang konsumsi di Bursa Efek Indonesia (BEI) periode 2016-2018. Perusahaan sektor industri barang konsumsi merupakan sektor industri yang tidak lepas dari kehidupan sehari-hari masyarakat. Semua orang membutuhkan makanan, minuman, obat-obatan dan keperluan rumah tangga lainnya untuk memenuhi kebutuhan hidupnya, sehingga perusahaan industri barang konsumsi tetap mampu bertahan walaupun sedang terjadi krisis ekonomi. Sektor Industri barang konsumsi di Bursa Efek Indonesia terbagi menjadi 5 sub sektor yaitu sub sektor makanan dan minuman, sub sektor rokok, sub sektor farmasi, sub sektor kosmetik dan sub sektor peralatan rumah tangga.Tabel 3. berikut menyajikan data jumlah perusahaan sektor indutri barang konsumsi berdasarkan sub sektornya masing-masing di Bursa Efek Indonesia (BEI) pada periode 2016-2018.

Tabel 3.

\begin{tabular}{|c|c|c|}
\hline Daftar Perusah & $\begin{array}{l}\text { Sektor Industri Bar } \\
\text { Indonesia Periode } 2\end{array}$ & $\begin{array}{l}\text { Konsumsi } \\
2018\end{array}$ \\
\hline No & Sub Sektor & $\begin{array}{c}\text { Jumlah } \\
\text { Perusahaan }\end{array}$ \\
\hline 1 & Makanan dan Minuman & 27 \\
\hline 2 & Rokok & 5 \\
\hline 3 & Farmasi & 10 \\
\hline 4 & Kosmetik & 6 \\
\hline 5 & Peralatan Rumah Tangga & 5 \\
\hline & Jumlah & 53 \\
\hline
\end{tabular}

Berdasarkan Tabel 3. perusahaan yang tergabung dalam sektor industri barang konsumsi pada tahun 2016-2018 di Bursa Efek Indonesia sebanyak 53 perusahaan sebagai populasi pada penelitian ini yang terbagi berdasarkan sub sektornya masing-masing. Sampel pada penelitian ini sebanyak 17 perusahaan yang dipilih berdasarkan kriteria tertentu.

Hasil statistik pada Tabel 4. menampilkan nilai minimum, nilai maksimum, rata-rata (mean) dan standar deviasi. Penelitian ini menggunakan variabel profitabilitas (ROE), likuiditas (CR), kebijakan dividen (DPR) dan nilai perusahaan (PBV). Berdasarkan kriteria sampel yang digunakan, diperoleh 17 perusahaan sektor industri barang konsumsi di BEI selama periode 2016-2018 sebagai sampel.

Berdasarkan Tabel 5. menunjukkan bahwa jumlah sampel data yang digunakan dalam penelitian ini berjumlah 51 data observasi sehingga dapat dijelaskan sebagai berikut: 1) nilai rata-rata (mean) ROE sebesar 0,1483 (14,83\%). 
Tabel 4.

Daftar Sampel Perusahaan Sektor Industri Barang Konsumsi

\begin{tabular}{ccll}
\hline No & $\begin{array}{c}\text { Kode } \\
\text { Saham }\end{array}$ & \multicolumn{1}{c}{ Nama Perusahaan } & \multicolumn{1}{c}{ Tanggal IPO } \\
\hline 1 & CINT & Chitose Internasional Tbk. & 27 Juni 2014 \\
2 & DLTA & Delta Djakarta Tbk. & 12 Februari 1984 \\
3 & DVLA & Darya-Varia Laboratoria Tbk. & 11-Nov-94 \\
4 & GGRM & Gudang Garam Tbk. & 27 Agustus 1990 \\
5 & HMSP & H.M. Sampoerna Tbk. & 15 Agustus 1990 \\
6 & ICBP & Indofood CBP Sukses Makmur Tbk. & 7 Oktober 2010 \\
7 & INDF & Indofood Sukses Makmur Tbk. & 14 Juli 1994 \\
8 & KAEF & Kimia Farma Tbk. & 4 Juli 2001 \\
9 & KINO & Kino Indonesia Tbk. & 11 Desember 2015 \\
10 & KLBF & Kalbe Farma Tbk. & 30 Juli 1991 \\
11 & MERK & Merck Tbk. & 23 Juli 1981 \\
12 & MYOR & Mayora Indah Tbk. & 4 Juli 1990 \\
13 & ROTI & Nippon Indosari Corpindo Tbk. & 28 Juni 2010 \\
14 & SIDO & Industri Jamu dan Farmasi Sido Muncul Tbk. & 18 Desember 2013 \\
15 & SKLT & Sekar Laut Tbk. & 08-Sep-93 \\
16 & TCID & Mandom Indonesia Tbk. & 23-Sep-93 \\
17 & TSPC & Tempo Scan Pacific Tbk. & 17 Juni 1994 \\
\hline Sumber: Www.idx.co.id (2019) &
\end{tabular}

Tabel 5.

Hasil Uji Statistik Deskriptif

\begin{tabular}{lrrrrr}
\hline & N & Minimum & Maximum & Mean & Std. Deviation \\
\hline ROE & 51 & 0,03 & 0,37 & 0,1483 & 0,08011 \\
CR & 51 & 1,13 & 8,64 & 3,3139 & 1,97772 \\
DPR & 51 & 0,17 & 1,13 & 0,5119 & 0,25112 \\
PBV & 51 & 0,73 & 16,13 & 4,2163 & 3,31965 \\
Valid N (listwise) & 51 & & & & \\
\hline
\end{tabular}

Sumber: www.idx.co.id (data diolah, 2019)

Nilai minimum sebesar $0,03(3,0 \%)$ dimiliki oleh PT Chitose Internasional Tbk (CINT) pada tahun 2018. Nilai maksimum sebesar 0,37 (37,0\%) dimilik oleh PT H.M. Sampoerna Tbk (HMSP) pada tahun 2016. 2) nilai rata-rata (mean) CR sebesar 3,3139 (331,39\%). Nilai minimum sebesar 1,13 (113,0\%) dimiliki oleh PT Indofood Sukses Makmur Tbk (INDF) pada tahun 2018. Nilai maksimum sebesar 8,64 (864,0\%) dimiliki oleh PT Delta Djakrta Tbk (DLTA) pada tahun 2017. 3) nilai rata-rata (mean) DPR sebesar 0,5119 (51,19\%). Nilai minimum sebesar 0,17 $(17,0 \%)$ dimiliki oleh PT Sekar Laut Tbk (SKLT) pada tahun 2016. Nilai maksimum sebesar 1,13 (113,0\%) dimiliki oleh PT Delta Djakrta Tbk (DLTA) pada 
tahun 2018. 4) nilai rata-rata (mean) PBV sebesar 4,2163 kali. Nilai minimum sebesar 0,73 kali dimiliki oleh PT Chitose Internasional Tbk (CINT) pada tahun 2018. Nilai maksimum sebesar 16,13 kali dimiliki oleh PT H.M. Sampoerna Tbk (HMSP) pada tahun 2017.

Tabel 6.

Hasil Analisis Regresi Linier Berganda

\begin{tabular}{cccc}
\hline No. & Variabel & Koefisien Regresi & Sig. \\
\hline & (Constant) & 0,342 & 0,591 \\
1 & ROE & 43,084 & 0,000 \\
2 & CR & $-0,299$ & 0,073 \\
3 & DPR & $-2,975$ & 0,085 \\
\hline R Square $=0,704$ & & & $\mathrm{~F}=37,274$ \\
Adjusted R Square $=0,685$ & & Sig $=0,000$
\end{tabular}

Sumber: www.idx.co.id (data diolah, 2019)

$$
\mathrm{Y}=0,342+43,084 \mathrm{X}_{1}-0,299 \mathrm{X}_{2}-2,975 \mathrm{X}_{3}
$$

Berdasarkan persamaan regresi linier berganda maka dapat dilakukan analisis sebagai berikut: 1) Koefisien profitabilitas (ROE) sebesar 43,084. Memiliki arti bahwa adanya hubungan yang searah antara nilai perusahaan dengan ROE, jika profitabilitas (ROE) meningkat 1 satuan maka nilai perusahaan akan meningkat sebesar 43,084 kali dengan asumsi variabel lainnya konstan. 2) Koefisien likuiditas (CR) sebesar -0,299. Memiliki arti bahwa adanya hubungan yang berlawanan antara nilai perusahaan dengan CR, jika likuiditas (CR) meningkat 1 satuan maka nilai perusahaan akan menurun sebesar 0,299 kali dengan asumsi variabel lainnya konstan. 3) Koefisien kebijakan dividen (DPR) sebesar -2,975. Memiliki arti bahwa adanya hubungan yang berlawanan antara nilai perusahaan dengan DPR, jika kebijakan dividen (DPR) meningkat 1 satuan maka nilai perusahaan akan menurun sebesar 2,975 kali dengan asumsi variabel lainnya konstan.

Berdasarkan hasil persamaan regresi linier berganda tersebut menunjukkan koefisien regresi variabel bebas yang bertanda positif berarti mempunyai pengaruh yang searah terhadap nilai perusahaan (PBV) sedangkan koefisien yang bertanda negatif mempunyai pengaruh yang berlawanan terhadap nilai perusahaan (PBV).

Tabel 7.

Hasil Uji Normalitas

\begin{tabular}{llr}
\hline & & Unstandardized Residual \\
\hline $\mathrm{N}$ & & 51 \\
Normal Parameters & Mean & 0,0000000 \\
& Std. Deviation & 1,80587254 \\
Most Extreme Differences & Absolute & 0,096 \\
& Positive & 0,096 \\
& Negative & $-0,065$ \\
Test Statistic. & & 0,096 \\
Asymp. Sig. (2-tailed) & & 0,200 \\
\hline Sumber: www.idx.co.id (data diolah, 2019) &
\end{tabular}


Berdasarkan Tabel 7. hasil uji normalitas residual sudah berdistribusi normal, yang ditunjukkan dari nilai signifikasi Kolmogorov Smirnov (K-S) sebesar 0,2 lebih besar dari 0,05. Hal ini berarti data residual terdistribusi normal.

Tabel 8.

Hasil Uji Autokorelasi

\begin{tabular}{|c|c|c|c|c|c|}
\hline Model & $\mathbf{R}$ & R Square & $\begin{array}{c}\text { Adjusted R } \\
\text { Square } \\
\end{array}$ & $\begin{array}{c}\text { Std. Error of the } \\
\text { Estimate }\end{array}$ & Durbin-Watson \\
\hline 1 & $0,839^{a}$ & 0,704 & 0,685 & 1,86262 & 2,044 \\
\hline
\end{tabular}

Berdasarkan Tabel 8. nilai Durbin-Watson (DW-test) sebesar 2,044 dengan level signifikansi 5\%, untuk $\mathrm{n}=51$. Model regresi yang baik tidak mengandung gejala autokorelasi dengan kriteria $\mathrm{du}<\mathrm{dw}<4-\mathrm{du}$. Pada penelitian ini diperoleh $\mathrm{dL}=1,427$ dan $\mathrm{dU}=1,675$. Maka 1,675 $<2,044<2,325$, maka dapat disimpulkan bahwa dalam regresi linier ini tidak terdapat autokorelasi positif maupun autokorelasi negatif atau dapat disimpulkan bahwa model regresi ini bebas dari gejala autokorelasi sehingga layak untuk memprediksi.

Tabel 9.

Hasil Uji Multikolinearitas

\begin{tabular}{|c|c|c|}
\hline \multirow[b]{2}{*}{ Variabel } & \multicolumn{2}{|c|}{ Collinearity Statistics } \\
\hline & Tolerance & VIF \\
\hline ROE & 0,464 & 2,155 \\
\hline CR & 0,670 & 1,493 \\
\hline DPR & 0,386 & 2,592 \\
\hline
\end{tabular}

Pada Tabel 9. memperlihatkan hasil tolerance dan variance inflation factor (VIF) masing-masing variabel yang memiliki nilai tolerance lebih besar dari $10 \%$ dan nilai variance inflation factor (VIF) lebih kecil dari 10. Berdasarkan hasil tersebut dapat disimpulkan bahwa model regresi dalam penelitian ini tidak mengandung gejala multikolinearitas antara variabel bebas.

Tabel 10.

Hasil Uji Heteroskedastisitas

\begin{tabular}{lllcccc}
\hline & & Unstandardized \\
& & Residual & ROE & CR & DPR \\
\hline $\begin{array}{l}\text { Spearman's } \\
\text { rho }\end{array}$ & Unstandardized & Correlation & 1,000 & $-0,246$ & 0,057 & $-0,129$ \\
& Residual & Coefficient & & & & \\
& & Sig. (2-tailed) & - & 0,082 & 0,692 & 0,366 \\
& & $\mathrm{~N}$ & 51 & 51 & 51 & 51 \\
\hline
\end{tabular}

Sumber: www.idx.co.id (data diolah, 2019)

Berdasarkan hasil pengujian yang ditunjukkan pada Tabel 10. maka diperoleh hasil uji heteroskedastisitas masing-masing variabel bebas yang memiliki nilai signifikansi > 0,05 yaitu nilai signifikansi profitabilitas (ROE) sebesar 0,082, likuiditas (CR) sebesar 0,692 dan kebijakan dividen (DPR) sebesar 0,366. Dengan 
demikian dapat dikatakan bahwa dalam model regresi ini tidak terdapat gejala heteroskedastisitas.

Tabel 11.

Hasil Uji Kelayakan Model (Uji F)

\begin{tabular}{llccccc}
\hline Model & & Sum of Squares & Df & Mean Square & F & Sig. \\
\hline 1. & Regression & 387,946 & 3 & 129,315 & 37,274 & $0,000^{\mathrm{b}}$ \\
& Residual & 163,059 & 47 & 3,469 & & \\
& Total & 551,005 & 50 & & & \\
\hline
\end{tabular}

Sumber: www.idx.co.id (data diolah, 2019)

Berdasarkan Tabel 11. diketahui hasil uji kelayakan model (uji F) menunjukkan bahwa profitabilitas, likuiditas dan kebijakan dividen berpengaruh terhadap nilai perusahaan dengan nilai signifikansi $0,000<0,05$ maka dapat disimpulkan bahwa model ini layak digunakan dalam penelitian. Ini berarti bahwa ada pengaruh secara bersama-sama (stimulan) antara variabel bebas yaitu ROE, CR dan DPR terhadap variabel terikat yaitu PBV.

Tabel 12.

Hasil Uji Koefisien Determinasi $\left(\mathbf{R}^{2}\right)$

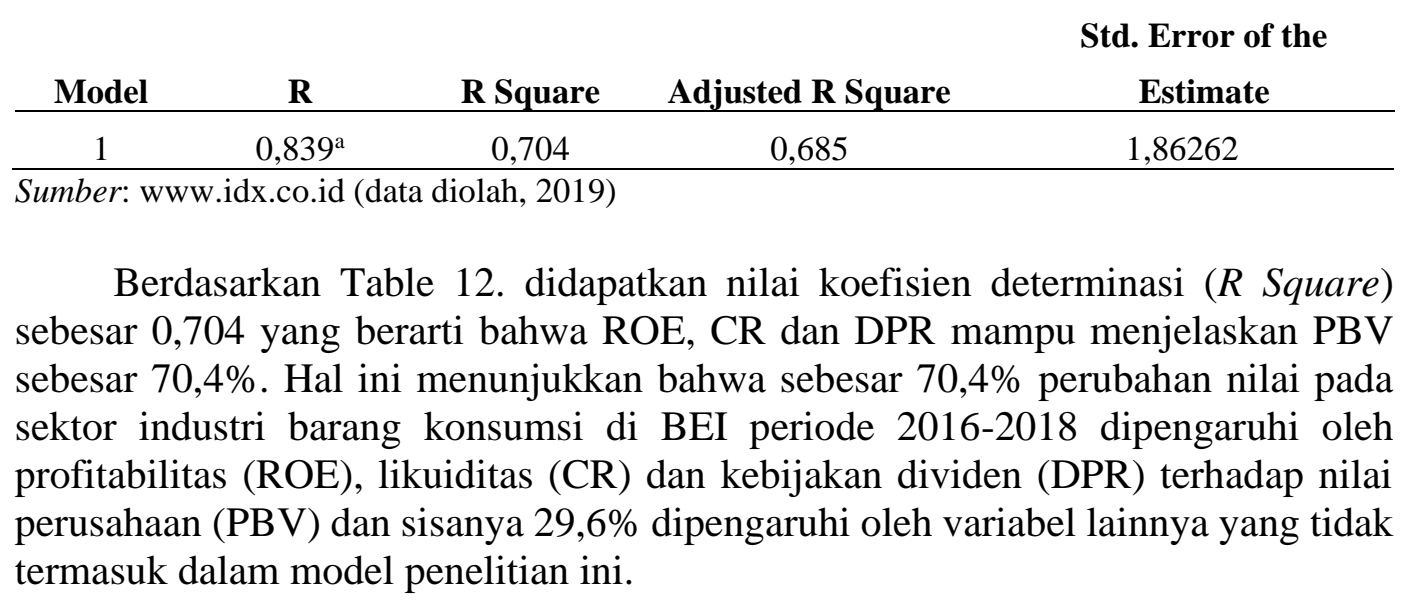

Tabel 13.

Hasil Uji Hipotesis (Uji t)

\begin{tabular}{|c|c|c|c|c|c|c|}
\hline \multirow{2}{*}{\multicolumn{2}{|c|}{ Model }} & \multicolumn{2}{|c|}{ Unstandardized Coefficients } & \multirow{2}{*}{$\begin{array}{c}\begin{array}{c}\text { Standardized } \\
\text { Coefficients }\end{array} \\
\text { Beta } \\
\end{array}$} & \multirow[b]{2}{*}{$\mathbf{T}$} & \multirow[b]{2}{*}{ Sig. } \\
\hline & & B & Std. Error & & & \\
\hline \multirow[t]{4}{*}{1} & (Constant) & 0,342 & 0,633 & & 0,541 & 0,591 \\
\hline & ROE & 43,084 & 4,827 & 1,040 & 8,925 & 0,000 \\
\hline & CR & $-0,299$ & 0,163 & $-0,178$ & $-1,836$ & 0,073 \\
\hline & DPR & $-2,975$ & 1,689 & $-0,225$ & $-1,762$ & 0,085 \\
\hline
\end{tabular}

Sumber: www.idx.co.id (data diolah, 2019)

Berdasarkan Tabel 13. hasil uji t dapat disimpulkan sebagai berikut: 1) Pengaruh profitabilitas terhadap nilai perusahaan ditemukan Sig. $t=0,000<0,05$ maka profitabilitas (ROE) berpengaruh positif dan signifikan terhadap nilai 
perusahaan sektor industri barang konsumsi di BEI periode 2016-2018. 2) Pengaruh variabel likuiditas terhadap nilai perusahaan ditemukan Sig. $\mathrm{t}=0,073>0,05$ maka likuiditas (CR) berpengaruh negatif dan tidak signifikan terhadap nilai perusahaan sektor industri barang konsumsi di BEI periode 2016-2018. 3) Pengaruh variabel kebijakan deviden terhadap nilai perusahaan ditemukan Sig. $t=0,085>0,05$ maka kebijakan dividen (DPR) berpengaruh negatif dan tidak signifikan terhadap nilai perusahaan sektor industri barang konsumsi di BEI periode 2016-2018.

Profitabilitas berpengaruh positif dan signifikan terhadap nilai perusahaan pada sektor industri barang konsumsi di BEI periode 2016-2018. Semakin tinggi profitabilitas menunjukkan tingkat efisiensi perusahaan dalam memperoleh laba dan sebagai ukuran efektivitas pengelolaan manajemen perusahaan. Semakin tinggi profitabilitas perusahaan maka nilai perusahaan akan semakin tinggi. Hal ini menandakan bahwa perusahaan memiliki kinerja dan prospek yang baik dimasa depan sehingga dapat memicu investor untuk ikut meningkatkan permintaan saham dengan melakukan investasi. Para investor akan tertarik berinvestasi pada perusahaan yang memiliki profitabilitas yang tinggi.

Berdasarkan signaling theory, sebuah perusahaan yang mempublikasikan informasi laporan keuangannya bertujuan untuk mempertahankan minat investor agar tidak terjadi asimetris informasi antara pihak perusahaan dengan luar perusahaan. Profitabilitas yang tinggi dan stabil akan menjadi sinyal positif bagi investor terkait dengan kinerja perusahaan sehingga berdampak pada meningkatnya nilai perusahaan. Hasil ini didukung oleh penelitan yang dilakukan oleh (Melinda Yanti Putu Diah, 2019) yang menyatakan bahwa profitabilitas berpengaruh positif dan signifikan terhadap nilai perusahaan. Begitu pula dengan penelitian yang dilakukan oleh (Putra \& Lestari, 2016), (Maha Dewi \& Sudiartha, 2017), (Raju \& Asaduzzaman, 2017).

Likuiditas berpengaruh negatif dan tidak signifikan terhadap nilai perusahaan sektor industri barang konsumsi di BEI periode 2016-2018. Current ratio (CR) yang rendah biasanya dianggap menunjukkan terjadinya masalah dalam likuiditas. Current ratio $(C R)$ yang terlalu tinggi juga kurang baik, karena hal ini menunjukkan bahwa manajemen perusahaan kurang mampu mengelola manajemen kas yang dapat mengurangi kemampuan perusahaan memperoleh laba, sehingga hal ini dapat memberikan sinyal negatif kepada investor.

Sinyal negatif ini dapat mempengaruhi keputusan investor dalam berinvestasi karena dianggap tidak mampu mensejahterakan para pemegang saham. Padahal untuk meningkatkan nilai perusahaan, perusahaan harus bisa mensejahterakan para pemegang saham agar investor tetap percaya untuk berinvestasi pada perusahaan tersebut. Hasil penelitian ini sejalan dengan penelitian yang dilakukan oleh (Dewi, L.S \& Abundanti, 2019) yang menyatakan bahwa likuiditas berpengaruh negatif dan tidak signifikan terhadap nilai perusahaan. Begitu pula penelitian yang dilakukan oleh (Sudiani \& Darmayanti, 2016), (Tauke, 2017), (Chasanah \& Adhi, 2017), (Memon et al., 2017), (Alfi \& Safarzadeh, 2016), (Patricia et al., 2018), (Permana \& Rahyuda, 2018).

Kebijakan dividen berpengaruh negatif dan tidak signifikan terhadap nilai perusahaan sektor industri barang konsumsi di BEI periode 2016-2018. Hal ini berarti kenaikan dividen yang akan dibagi oleh para pemegang saham tidak selalu 
diikuti dengan meningkatnya nilai perusahaan, sehingga kebijakan dividen bukan merupakan faktor utama yang mempengaruhi para investor untuk berinvestasi. Pembayaran dividen tidak berpengaruh terhadap kemakmuran pemegang saham karena nilai perusahaan ditentukan oleh earning power dari aset perusahaan. Maka nilai perusahaan lebih ditentukan oleh keputusan investasi.

Kebijakan dividen bukan faktor utama bagi investor untuk menilai suatu perusahaan. Semakin tinggi dividen yang dibagikan belum tentu menyebabkan meningkatnya nilai perusahaan, karena kebijakan dividen belum menjamin membuat kemakmuran pemegang saham meningkat. Menurut (Suwardika \& Mustanda, 2017) hal yang lebih diperhatikan oleh investor adalah kinerja perushaan dan rasio-rasio keuangan yang terdapat pada laporan keuangan perusahaan serta nama baik perusahaan sebelum memutuskan untuk berinvestasi. Hasil ini sejalan dengan penelitian yang dilakukan oleh (Melinda Yanti Putu Diah, 2019), (Apriliyanti et al., 2019), (Topak \& Dereli, 2018), (Martha et al., 2018) yang mendapatkan hasil bahwa kebijakan dividen berpengaruh negatif dan tidak signifikan terhadap nilai perusahaan.

\section{SIMPULAN}

Kesimpulan dari penelitian ini yaitu Profitabilitas yang diproksikan dengan Return on Equity (ROE) berpengaruh positif dan signifikan tehadap nilai perusahaan sektor industri barang konsumsi di BEI periode 2016-2018. Hal ini berarti bahwa meningkatnya profitabilitas memberikan sinyal positif kepada investor untuk berinvetasi, sehingga profitabilitas menjadi faktor penting bagi manajemen perusahaan dalam meningkatkan nilai perusahaan.

Likuiditas yang diproksikan dengan Current Ratio (CR) berpengaruh negatif dan tidak signifikan terhadap nilai perusahaan sektor industri barang konsumsi di BEI periode 2016-2018. Hal ini berarti bahwa tingginya likuiditas perusahaan tidak diikuti dengan meningkatnya nilai perusahaan, karena perusahaan kurang mampu mengelola efektivitas dan efisiensi manajemen kas untuk mengoptimalkan keuntungan perusahaan.

Kebijakan dividen yang diproksikan dengan Dividen Payout Ratio (DPR) berpengaruh negatif dan tidak signifikan terhadap nilai perusahaan sektor industri barang konsumsi di BEI periode 2016-2018. Hal ini berarti bahwa besarnya dividen yang dibagikan perusahaan tidak selalu dapat mensejahterakan para pemegang saham dan meningkatkan nilai perusahaan.

Saran yang dapat diberikan yaitu: Bagi investor dan perusahaan diharapkan untuk lebih memperhatikan profitabilitas sebagai faktor utama yang paling mempengaruhi nilai perusahaan, karena profitabilitas memiliki pengaruh yang signifikan terhadap nilai perusahaan. Bagi peneliti selanjutnya diharapkan untuk melakukan penelitian lebih lanjut dengan variabel lain yang mempengaruhi nilai perusahaan serta menambah periode waktu penelitian dan dilakukan pada perusahaan lainnya untuk mendaptakan hasil penelitian yang lebih baik. 


\section{REFERENSI}

Haryanto. (2016). Effect of Liquidity and Profitability to Bank Stock Return in Indonesia Stock Exchange (IDX). International Journal of Academic Research in Accounting, Finance and Management Sciences, 6(3), 131-145. https://doi.org/10.6007/ijarafms/v6-i3/2219

Adefemi, O., Adaramola, A., Akosile, M., \& Obalade, G. (2018). Effect of Dividend and Earnings on Stock Price Movement in Nigerian Banking Sector. Acta Universitatis Danubius. Economica, 14(5), 229-243.

Adesina, K., Uwuigbe, U., Uwuigbe, O. R., \& Oriabe, S. (2017). Dividend Policy and Share Price Valuation in Nigerian Banks EuroEconomica Dividend Policy and Share Price Valuation in Nigerian Banks. 1(September).

Alfi, S. and Safarzadeh, M. . (2016). Effect of Capital Structure and Liquidity on Firm Value. IJABER, 14(14), 10143-10153.

Apriliyanti, V., Hermi, H., \& Herawaty, V. (2019). Pengaruh Kebijakan Hutang, Kebijakan Dividen, Profitabilitas, Pertumbuhan Penjualan Dan Kesempatan Investasi Terhadap Nilai Perusahaan Dengan Ukuran Perusahaan Sebagai Variabel Moderasi. Jurnal Magister Akuntansi Trisakti, 6(2), 201. https://doi.org/10.25105/jmat.v6i2.5558

Astuti, N. K. B., \& Yadnya, I. P. (2019). Pengaruh Profitabilitas, Likuiditas, Dan Ukuran Perusahaan Terhadap Nilai Perusahaan Melalui Kebijakan Dividen. E-Jurnal Manajemen Universitas Udayana, 8(5), 3275. https://doi.org/10.24843/ejmunud.2019.v08.i05.p25

Astuty, P. (2017). The influence of fundamental factors and systematic risk to stock prices on companies listed in the Indonesian stock exchange. European Research Studies Journal, 20(4), 230-240.

Ayem, S., \& Nugroho, R. (2016). PENGARUH PROFITABILITAS, STRUKTUR MODAL, KEBIJAKAN DEVIDEN, DAN KEPUTUSAN INVESTASI TERHADAP NILAI PERUSAHAAN (Studi Kasus Perusahaan Manufaktur Yang Go Publik di Bursa Efek Indonesia) PERIODE 2010 - 2014. Jurnal Akuntansi, 4(1), 31-39. https://doi.org/10.24964/ja.v4i1.125

Brigham, E.F. and Houston, J. (2018). Dasar-dasar manajemen keuangan (14th ed.). Salemba Empat.

Chasanah, A. N., \& Adhi, D. K. (2017). PROFITABILITAS, STRUKTUR MODAL DAN LIKUIDITAS PENGARUHNYA TERHADAP NILAI PERUSAHAAN PADA PERUSAHAAN REAL ESTATE YANG LISTED DI BEI (Profitability, Capital Structure and Liquidity Influence on Corporate Value on Listed Real Estate Companies in BEI, 2012-20. Fokus Ekonomi, 
12(2), 131-136.

Damayanti, I. F. I., Rizal, N., \& Munir, M. (2018). Pengaruh Kinerja Keuangan Terhadap Nilai Perusahaan Pada Perusahaan Makanan dan Minuman Yang Terdaftar Di Bursa Efek Indonesia Tahun 2014-2016. Jurnal Riset Akuntansi, 1(September), 162-171.

Dewi, L.S \& Abundanti, N. (2019). PENGARUH PROFITABILITAS, LIKUIDITAS, KEPEMILIKAN INSTITUSIONAL DAN KEPEMILIKAN MANAJERIAL TERHADAP NILAI PERUSAHAAN. E-Jurnal Manajemen Universitas Udayana, 8(10), 6099-6118.

Faraz, Z., Ishfaq, S., \& Khan, A. (2017). Dividend Policy and Shareholder' S Wealth : Evidence From Cement Sector of Pakistan. International Journal of Information, Business and Management, 9(3), 27-40.

Gayatri, N., \& Mustanda, I. (2014). Pengaruh Struktur Modal, Kebijakan Dividen Dan Keputusan Investasi Terhadap Nilai Perusahaan. E-Jurnal Manajemen Universitas Udayana, 3(6), 1700-1718.

Gede, L., \& Artini, S. (2019). PERUSAHAAN Fakultas Ekonomi dan Bisnis Universitas Udayana ( Unud ), Bali , Indonesia Manajemen keuangan memiliki tujuan memaksimumkan nilai dari perusahaan atau kemakmuran dari pemegang saham perusahaan . Wiagustini ( 2014:9) menyatakan bahwa memaksim. 8(2), 7717-7745.

Husnan, S. (2015). Dasar-Dasar Manajemen Keuangan (6th ed.). BPFE.

Kasmir. (2013). Dasar-Dasar Perbankan. (PT Raja Grafindo Persada (ed.)).

Maha Dewi, D., \& Sudiartha, G. (2017). Pengaruh Profitabilitas, Ukuran Perusahaan, Dan Pertumbuhan Aset Terhadap Struktur Modal Dan Nilai Perusahaan. E-Jurnal Manajemen Universitas Udayana, 6(4), 2222-2252.

Mahdaleta, E., Muda, I., Nasir, G. M., Mahdaleta, E., \& Muda, I. (2016). Effects of Capital Structure and Profitability on Corporate Value with Company Size as the Moderating Variable of Manufacturing Companies Listed on Indonesia Stock Exchange. Academic Journal of Economic Studies, 2(3), 30-43.

Martha, L., Sogiroh, N. U., Magdalena, M., Susanti, F., \& Syafitri, Y. (2018). Profitabilitas Dan Kebijakan Dividen Terhadap Nilai Perusahaan. Jurnal Benefita, 3(2), 227. https://doi.org/10.22216/jbe.v3i2.3493

Melinda Yanti Putu Diah, A. N. (2019). Penelitian ini dilakukan untuk menguji pengaruh profitabilitas,. Manajemen, 8(9), 5632-5651. 
Memon, N.M., Channa, N. and Khoso, I. (2017a). Impact of Dividend Policy on Market Prices of Share: Evidence of Pakistan. Journal of Business Strategies, 11(2), 57-72.

Memon, N.M., Channa, N. and Khoso, I. (2017b). Impact of Dividend Policy on Market Prices of Share: Evidence of Pakistan. Journal of Business Strategies, $11(2), 57-72$.

Musabbihan, N. A., \& Purnawati, N. K. (2018). Pengaruh Profitabilitas Dan Kebijakan Dividen Terhadap Nilai Perusahaan Dengan Struktur Modal Sebagai Pemediasi. E-Jurnal Manajemen Universitas Udayana, 7(4), 1979. https://doi.org/10.24843/ejmunud.2018.v07.i04.p10

Ong, E. (2016). Technical Analysis for Mega Profit. PT. Gramedia Pustaka Utama.

Patricia, Bangun, P., \& Tarigan, M. U. (2018). Pengaruh Profitabilitas, Likuiditas, dan Ukuran Perusahaan Terhadap Nilai Perusahaan Dengan Kinerja Keuangan Sebagai Variabel Intervening (Studi Empiris Pada Perusahaan Manufaktur Yang Terdaftar Di Bursa Efek Indonesia). Manajemen Bisnis Kompetensi, 13(1), 25-42.

Permana, A. A. N. B. A., \& Rahyuda, H. (2018). Pengaruh Profitabilitas, Solvabilitas,Likuiditas, Dan Inflasi Terhadap Nilai Perusahaan. E-Jurnal Manajemen Universitas Udayana, 1577. https://doi.org/10.24843/ejmunud.2019.v08.i03.p15

Pranama, I.G.N.A.D dan Mustanada, I. . (2016). Pengaruh Profitabilitas dan Size Terhadap Nilai Perusahaan dengan CSR sebagai Variabel Pemoderasi. EJurnal Manajemen Universitas Udayana, 5(1), 561-594.

Putra, A.A.N.D.A. dan Lestari, P. V. (2016). Pengaruh Kebijakan Dividen, Likuiditas, Profitabilitas dan Ukuran Perusahaan terhadap Nilai Perusahaan. E-Jurnal Manajemen Universitas Udayana, 5(7), 4044-4070.

Rai Prastuti, N., \& Merta Sudiartha, I. (2016). Pengaruh Struktur Modal, Kebijakan Dividen, Dan Ukuran Perusahaan Terhadap Nilai Perusahaan Pada Perusahaan Manufaktur. E-Jurnal Manajemen Universitas Udayana, 5(3), $1572-1598$.

Raju, M. B. H., \& Asaduzzaman, A. H. M. (2017). The Impact of Dividend Policy on Stock Price: A Study of Fuel, Power and Cement Industry in Bangladesh. IOSR Journal of Economics and Finance, 08(03), 84-91. https://doi.org/10.9790/5933-0803048491

Sartono, A. (2014). Manajemen Keuangan Teori Dan Aplikasi (4th ed.). BPFE. 
Sharif, T., Purohit, H., \& Pillai, R. (2015). Analysis of Factors Affecting Share Prices: The Case of Bahrain Stock Exchange. International Journal of Economics and Finance, 7(3). https://doi.org/10.5539/ijef.v7n3p207

Sitorus, T. and Elinarty, S. (2017). The Influence of Liquidity and Profitability Toward the Growth at Stock Price Mediated by The Dividends Paid Out (Case in Banks Listed in Indonesia Stock Exchange). Journal of Economics, Business, and Accountancy Ventura, 19(3), 377-392.

Suarnawa, I., \& Abundanti, N. (2016). Profitabilitas Dan Likuiditas Sebagai Prediktor Kebijakan Dividen Dan Nilai Perusahaan Pada Perusahaan Manufaktur Dibei. E-Jurnal Manajemen Universitas Udayana, 5(9), 55855611.

Sudiani, N., \& Darmayanti, N. (2016). Pengaruh Profitabilitas, Likuiditas, Pertumbuhan, Dan Investment Opportunity Set Terhadap Nilai Perusahaan. E-Jurnal Manajemen Universitas Udayana, 5(7), 4545-4547.

Suwardika, I.N.A. dan Mustanda, I. . (2017). Pengaruh Leverage, Ukuran Perusahaan, Pertumbuhan Perusahaan dan Profitabilitas terhadap Nilai Perusahaan pada Perusahaan Properti. E-Jurnal Manajemen Universitas Udayana, 6(3), 1248-1277.

Tauke, Y. P. M. E. T. (2017). Pengaruh Kinerja Keuangan Terhadap Nilai Perusahaan Real Estate and Property Yang Terdaftar Di Bursa Efek Indonesia Tahun the Effect of Financial Performance on the Value of Real Estate and Propertycompanies Listed on the Indonesian Stock Exchange in 2012. 919 Jurnal EMBA, 5(2), 919-927.

Topak, M. S., \& Dereli, H. (2018). The Effect of Dividend Policy on Stock Price: Evidence from An Emerging Country. Journal of Business Research - Turk, 10(4), 1186-1197. https://doi.org/10.20491/isarder.2018.569

Tuil, S., Nurnajamuddin, S. and N. (2017). Determinants of Profitability and Firm Value: Evidence from Indonesia Banks, Faculty of Economics, Muslim University of Indonesia. IRA International Journal of Management, 7(1), 8495.

Velankar, N., Chandani, A., \& Ahuja, A. K. (2017). Impact of EPS and DPS on Stock price: A Study of Selected Public Sector Banks of India. Prestige International Journal of Management \& IT-Sanchayan, 6(1), 111-121. http://pjitm.com/Doc/jan-july2017/PAPER8.pdf

Wiagustini, N. L. (2014). Dasar-dasar Manajemen Keuangan. Udayana University Press. 
Kadek Yuliana Dewi, Pengaruh Profitabilitas,Likuiditas...

Yanti, I. G. A. D. N., \& Darmayanti, N. P. A. (2019). Pengaruh Profitabilitas, Ukuran Perusahaan, Struktur Modal, Dan Likuiditas Terhadap Nilai Perusahaan Makanan Dan Minuman. E-Jurnal Manajemen Universitas Udayana, 8(4), 2297. https://doi.org/10.24843/ejmunud.2019.v08.i04.p15 